9. Janic M. An Analysis of the Concepts of Airport Sustainable Capacity and Development / M. Janic // Ist Intern. Conf. "Environmental Capacity at Airports". - The Manchester Metropolitan University. - Manchester, Great Britain. 2nd and 3rd Apr., 2001. - P. 1-20.

10. Green logistics. Improving the environmental sustainability of logistics / Alan McKinnon, Sharon Cullinane, Michael Browne, Anthony Whiteing. - London: Chartered Institute of Logistics and Transport, 2010. $-372 \mathrm{p}$.

DOI: doi.org/10.18372/38211

UDC: 502.175:629.3.015.6:656.1(045)

\title{
3.5 NOISE MONITORING FOR IMPROVEMENT OF OPERATIONAL PERFORMANCES OF THE AIRCRAFT IN VICINITY OF AIRPORTS
}

\author{
Mikhal Bukalal, Oleksandr Zaporozhets ${ }^{2}$, \\ Volodymyr Isaienko ${ }^{3}$, Andrzej Chyla ${ }^{l}$
}

The aircraft noise is usually the single or somewhere one of the most important local impact factor arising from airport operations which, unless managed effectively, has the potential to constrain the ability of airports to grow in response to demand and hence limit the social and economic benefits that future growth could bring [1]. People living around the airports are driven to complain when some nuisance factor (or stressor) in the environment gives rise to annoyance and/or sleep disturbance when this stressor reaches a threshold of tolerance. Polish Environmental Protection Law (EPL) [2] treats noise as an environmental pollution, hence this Act adopts the same general principles, obligations and forms of proceedings in relation to noise, as to other areas of environmental protection. The EPL also introduces to the legal system of environmental protection a new institution of the so-called noise areas - the areas where the noise level is exceeded to the extent that it requires corrective action via the recovery programs.

According to art. 179 of the EPL, airports are included in list of objects, whose operation may cause a negative acoustic impact on environment in significant areas, and the manager of such airport is obliged to draw up acoustic maps of the area every 5 years, during which the operation of the airport may exceed permissible noise levels for the environment. As required by EPL to control the impact of aircraft noise on population an area of limited usage (noise zone or obszar ograniczonego użytkowania in Polish - OOU) is created around any airport in Poland. This area arises when, from an ecological review or from an environmental impact assessment, required by the provisions of the Polish Act of 3 October 2008 on access to information about the environment and its protection, public participation in environmental protection and environmental impact assessments, or post-implementation analysis shows that despite the use of available technical, technological and organizational solutions, environmental quality standards outside the airport area can not be met.

Noise from the aircraft is limited by ICAO standards [3] and due to corresponding Polish Aviation Law, art. 53.1 [4] in the scope not reserved for EASA, the President of the Office shall examine compliance with the requirements to be met by aircraft in the scope of environmental protection against noise and pollution of land, water and air, as defined in international regulations and European Union law and regulations issued on based on paragraph 5. Regulation (EC) No 216/2008 of the European Parliament and of the Council of 20 February 2008 on common rules in the field of civil aviation and establishing a European Aviation Safety Agency EASA states that all aircraft (except aircraft specified in Annex II w / in regulation), they must meet the environmental protection requirements for noise in accordance with Annex XVI of the Convention on International Civil Aviation, December 7, 1944, also known as the Chicago Convention [3]. Meeting these requirements is confirmed by the Civil Aviation Office by issuing a noise certificate. 
Directive 80/51/EEC, as amended by Directive 83/206/EEC, set limits on the emission of such noise. Already in the eighties of the twentieth century, the European Communities' environmental action program stressed the need to take appropriate steps in this area. A concrete expression of these was the adoption by the Council of the European Communities on December 4, 1989 of the directive on the limitation of noise emissions from civil subsonic jet airplanes (89/629/EEC). It sought to establish stricter rules for reducing noise emissions, although airplanes with a maximum take-off mass of $34,000 \mathrm{~kg}$ or less and with a capacity of 19 or fewer seats were excluded from its scope.

The Member States of the Communities have been required to ensure that from November 1, 1990, civil subsonic jet airplanes registered after that day in their territory may not be operated in that territory or in the territory of another Member State unless they have been granted an noise certificate in accordance with standards at least equal to those specified in Volume 1, Chapter 3, Part II of Annex 16 to the Convention on International Civil Aviation. Exceptionally, exemptions from this prohibition are provided for:

- aircraft of historical significance;

- airplanes used by an entity from a Member State before 1 November 1989 under a stillexisting purchase or leasing agreement which in this context was registered in a third country;

- airplanes rented to a third country entity that have been temporarily removed from the register of a Member State of the Community for that reason;

- an aircraft which replaces another one destroyed in an accident and which the entity is unable to replace by a comparable noise-certified aircraft available on the market, provided, however, that the replacement aircraft will be registered within one year of the resulting damage;

- airplanes powered by engines with a transmission ratio of 2 or more.

The ICAO Balanced Approach (EC Directive 2002/30/EC) was transposed into Polish law though the Aviation Law (Noise Restrictions) [4] especially in its art.71a-71e, which were added to the law for this purposeon 29 of April 2004. They allowed the Head of the Civil Aviation Authority (CAA) to introduce by administrative decision the restrictions or prohibitions on performing air operations to reduce the noise emitted at the airport where, in the last three calendar years, no less than 50,000 air operations were carried out on average per year (In accordance with Directive 2002/30/EC). The applicable prohibitions or restrictions may apply to civil subsonic jet airplanes with a maximum take-off weight of not less than $34,000 \mathrm{~kg}$ or to accommodate, according to an airplane type certificate, more than nineteen passenger seats, excluding spaces reserved for crew only. As regards the discussed restrictions, marginal compliant planes are therefore located, i.e. with a cumulated noise margin of no more than $5 \mathrm{EPNdB}$. By the cumulative margin of noise, the legislator understands the sum of the differences between the permissible noise level and the noise level specified in the airworthiness certificate of the aircraft in terms of noise, according to measurements made at three reference points. The permissible sound level and reference points shall be determined taking into account Chapter 3 of Part II of Volume I of Annex 16 to the Convention on International Civil Aviation.

As the noise generated by aircraft can spread (including the spread of the real flight paths/tracks used in operation in airport under consideration, which are much wider than simply tracks shown in AIP for the airport and used for acoustic maps calculation usually), the OOU can also be extended analogically. To this end, environmental noise monitoring is carried out [5]. Measurement results are the basis for the development of acoustic maps that present average values in relation to the year. Noise maps are helpful in spatial planning and environmental protection processes and contribute to improving the acoustic climate of the city close to airport. This information is the basis for noise protection measures adoption - installing sound absorbing screens, additional planting trees and shrubs, or even changing the course of flights, arrival and departure procedures for aircraft operated in the airport under consideration. In any case the acoustical performances of the aircraft in operation are considered currently as one of the basic 
operational parameters, which may even to limit the operational capacity of the airport (sometimes called environmental in contrary to operational capacity - the limited number of flights per hour in airport under consideration, which allows to noise limits (limited levels of noise) for this airport in points of control, once again - the points of noise monitoring [5]).

Focusing on national regulations, we can say that one of the most important is the Act of April 21, 2001 [2]. Environmental Protection Law (Journal of Laws of 2008, No. 25, item 150, as amended), which specifies environmental protection principles and conditions for using its resources, is taking into account the requirements of sustainable development [6]. The provisions of executive law in the form of the ordinance of the Minister of the Environment of 1 October 2007 on the detailed scope of data included in acoustic maps and their layout and presentation are also important (Journal of Laws from 2007, No. 187, item 1340), ordinance of the Minister of the Environment of 1 October 2012 amending the regulation on permissible noise levels in the environment (Journal of Laws of 2012, item 1109), or the ordinance of the Minister of the Environment of November 10, 2010 on the method of determining the value of the indicator $\mathrm{L}_{\mathrm{DEN}}$ noise (Journal of Laws of 2010, No. 215, item 1414).

To evaluate the effect of the protection measures implemented, a comprehensive set of surveys to evaluate the short- and long-term effects should be undertaken. A number of the previous studies indicate that when changes in noise exposure are achieved by source-related measures (quieter aircraft and/or low noise flight procedures implemented, air traffic reduced, etc.), the responses could be higher than those predicted from the exposure-response relationships established from a more stable condition. In studies where the changes include noise screens or insulation efforts, the change may be smaller than predicted. For example, inside dwellings of the "experimental" group that received the noise reduction intervention, an average equivalent noise reduction of $7 \mathrm{dBA}$ was calculated inside the dwellings. But some of intervention studies show that people are often satisfied with an intervention regardless of the result of the intervention (Hawthorne effect). For example, one study show the positive effect equal to average equivalent noise reduction of $5 \mathrm{dBA}$ from informing a population about simply a noise monitoring program realised carefully around the airport. A review of different theoretical approaches explaining such differences can be found elsewhere.

The measurements of aircraft noise and the analysis of the results are necessary in order to protect correctly the local community living in the airport surrounding areas. Permanent or/and temporary noise monitoring to be undertaken usually in their local community on the assumption that aircraft noise will exceed what is considered 'acceptable' or legally permissible, and in this connection it is necessary to refer to the legislative controls on aircraft noise. The results show that for airports with low intensity of flights the long term equivalent sound level is heavily changing in relation with the long term maximum sound level, but for high intensity flight traffic this interrelation is quite stable. In the vicinity of airports with low flight intensity the maximum sound level as a noise impact metric is more sensitive than the equivalent level.In general case the purposes of monitoring are described elsewhere as:

1) to assess the current status of the resource to be managed or to help determine the priorities for management,

2) to determine if the desired management strategies were followed and produced the desired consequences,

3) to provide a greater understanding of the system being managed,and

4) to show that population involvement in noise management helps to reach the goals of the noise management program, etc.

Although today in most cases the main concern is the negative impact of aircraft noise, the highest goal is to show that measuring and monitoring the aircraft noise can be used for positive purposes. For example to show in routine mode what an aircraft exceeded the permissible level at a point of noise control, to show even why it was exceeded (flight procedure mistake happened or an 
aircraft type is quite noisy to be operated in particular conditions), any flight safety issues may be raised with monitoring system usage and at the same moment providing confidence to aviation as a whole. A very new challenge should be expected: how to deliver respite from aircraft noise at the airport that is valued by the community, which is consistent with efficient operations?

The number and location of the monitors is important depending upon the specific role they are to play. Quite usual elements of current aircraft noise monitoring systems are the air traffic data connection for flight events detection (correlation with noise events) and the latest point gathering the complaints from residents living around. A number of technologies is available currently to provide all these necessary functions independently from airports and air traffic providers and in cost-efficient manner, in such way being available for any airport (or community), which is interesting in efficient noise management.

The typical monitoring system (Fig. 1) consists of four main parts: data sources, data collecting and storing mechanism, data correlation and calculation tool and reporting module.

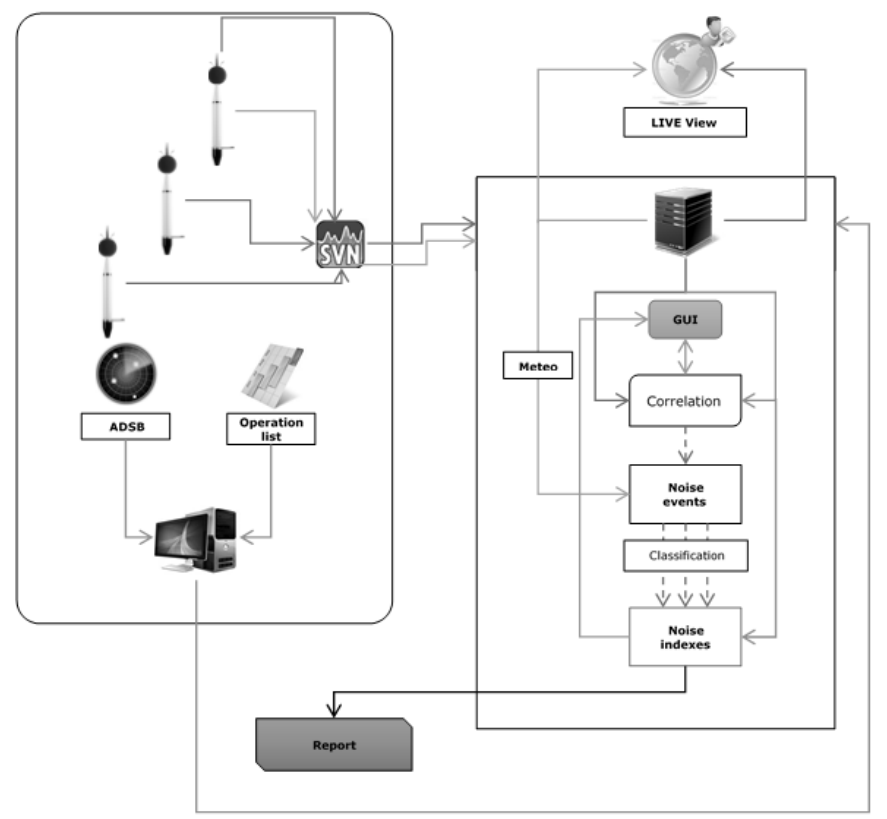

Fig. 1. Architecture of an exemplary noise monitoring system

Data souces:

- Noise monitoring stations, delivering measured acoustic data. For most cases the measured value is $\mathrm{L}_{\text {Aeq, }}$ logged with a $1 \mathrm{~s}$ step but other parameters, such as statistical levels, spectra etc. can also be used. Most measurement instruments can also provide pure audio signal, but despite its versatility and multiple recalculation possibilities it is highly impractical because of large amount of data, which has to be transferred, calculated and then stored.

-Flight path sources, such as radar or ADSB system. Accurate information about the aircraft location, synchronized with noise data is a relevant factor, which improves correct noise events recognition and makes spatial analyses possible.

- Meteorological stations, delivering information about current meteorological conditions. Such information is necessary to assess, whether the acoustic event is correctly measured. Moreover it is relevant for noise modelling. 
- Airport flight records, necessary for correct identification of a noise source and also for formal reasons.

The first step to ensure correct functioning of a monitoring system is to properly place the noise monitoring monitors (or terminals). There is a number of criteria which determine correctness of point placement but from technical point of view such placement should ensure low background noise levels, making events extraction possible.

Also there should be no obstacles in the vicinity of the measurement point. Properly located measurement points will strongly influence usefulness of a whole system.

All the data sources described above deliver information in different formats, with varying accuracy and stability. The main task of the collector component is to translate data into common format and common timebase and storing it in a database. This process also includes creating backups of raw data.

This is the key part of the whole monitoring system. Information stored in the system database is correlated, cross-referenced and calculated to obtain desired noise indexes, such as long term noise levels $\mathrm{L}_{\mathrm{DEN}}$ and $\mathrm{L}_{\mathrm{N}}$. Aircrafts' trajectories and airport operational information are used to extract noise events from the recorded sound level values. Various systems approach this issue differently. Whole task can be performed manually and automatically, with or without possibility of manual supervision. The ideal solution seems to be automatic noise extraction algorithm, which enables the user to manually verify (i.e. with partial audio recording) and correct the output. Each correction should at the same time improve accuracy of the algorithm. Such behavior can be obtained with machine learning approach based on the neural networks. After the events are correctly recognized desired indexes can be calculated.

After the calculations are completed usually the report has to be prepared, considering local requirements and regulations. Report has to cover whole range of activities that had taken place. The monitoring system should also often implement additional functionalities such as live preview of recorded values, automatic verification of data sources condition (most importantly noise monitoring stations).

The noise monitoring systems, which are installed at many airports around the world, range from simple systems measuring the noise levels of individual flights to complex systems, which accumulate and analyze noise data and monitor the flight tracks of aircraft, weather information, complaints of the neighboring population, and so on. It must supply factual analysis of aircraft operations and their consequences for environment and information useful to a surrounding community of the activities taken for environmental noise control. The data and analysis available from the system may improve planning efforts for noise control, such as in aircraft operation, or the best location for residential zones around the airport.

There are many national rules and guidelines that govern the installation of monitoring systems around international airports. During the last two decades around ten airports per year have provided new or improved installations. Initial systems were very simple in design and operation compared with more recent ones.

According to a special ICAO CAEP Work Program, an airport noise monitoring effort should [7]:

(a) compile data on methods used to describe aircraft noise exposure and applications of the data (Fig. 2a);

(b) determine the contribution (general and/or specific by type, route, airlines, etc.) of aircraft to the overall noise exposure (Fig. 2b); systems;

(c) collect data on the characteristics of airports with noise and/or flight path monitoring

(d) collect details of airport noise monitoring systems such as capabilities, data stored, technical support;

(e) compare calculated and monitored noise levels for a suitable sample of airports; 
(f) compare measured noise levels with certificated noise levels for a range of aircraft types and operating conditions;

(g) examine changes in measured noise exposure over a representative time period (Fig. 3);

(h) update advisory documents on methodologies and applications of noise contouring and monitoring, supplemented, for environmental noise management, by the elements of expert and decision-making systems.

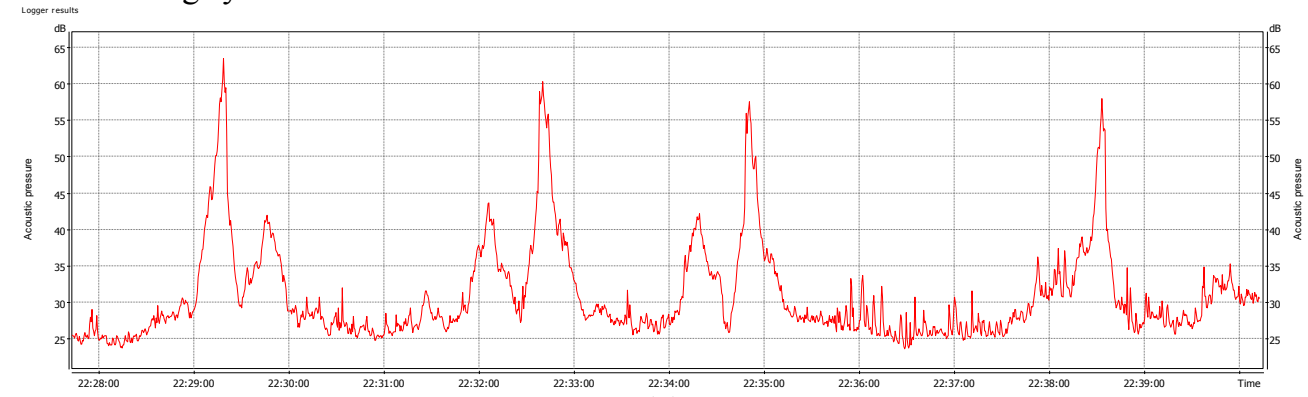

(a)

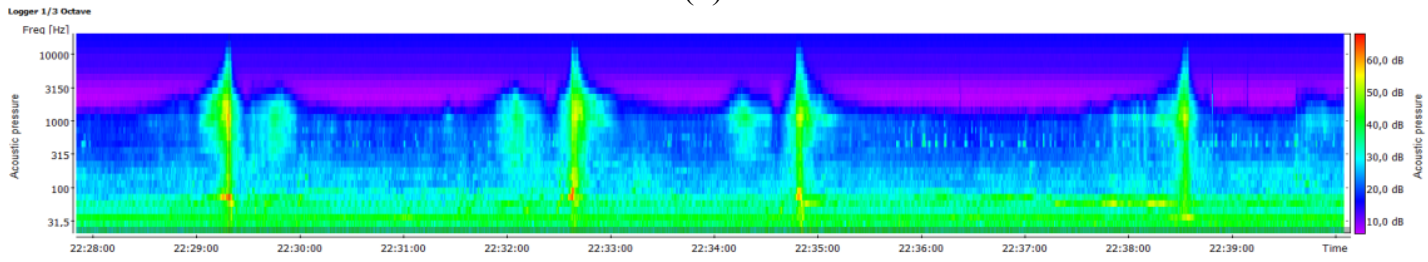

(b)

Fig. 2. Time history of the registered noise level of aviation noise $(a)$ along with the identification of acoustic events $(b)$

This collection of information:

(i) enables determination of the contribution of aircraft to overall noise exposure (Fig. 2);

(ii) enables detection of occurrences of excessive noise levels from aircraft operations;

(iii) enables assessment of the effects of operational and administrative procedures for noise control and compliance with these procedures and/or assess alternative flight procedures for noise control (the tool of objective assessment of efficiency of the proposed operational and administrative procedures for noise control in the vicinity of the airport);

(iv) assists in the planning of airspace usage issues;

(v) increases public confidence that airport related noise is being monitored to protect the public interest (Fig. 3);

(vi) enables validation of noise forecasts and forecasting techniques and their methodologies over an extended period of time (collection of data for noise contouring, system noise exposure forecasting and contouring with compiled data);

(vii) assists relevant authorities in land-use planning for developments and noise impact on areas in the vicinity of an airport;

(viii) enables assessment of a Quota Count system (special mitigation procedure which defines an appropriate number of flights of the aircraft of specific types during a specific period of the day without violation of noise limits), among other possible noise mitigation measures; and 
indicates official concern for airport noise by its jurisdiction and its governing bodies and enables provision of reports to, and responses to questions from, Government and other Members of Parliament, industry organizations, airport owners, community groups and individuals.

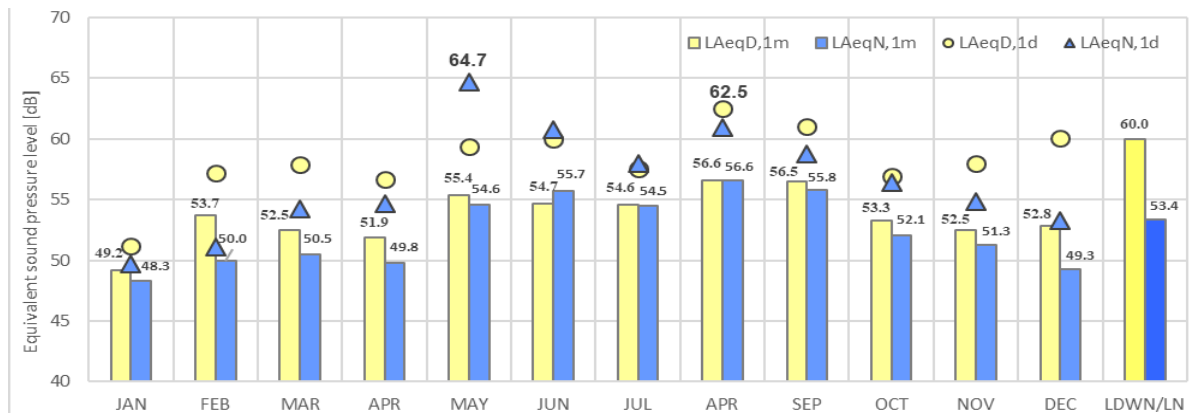

Fig. 3. Equivalent sound level from the period of one day, one month and year for day and night measured at one measurement point

Such a collection of information is basic for assessment of aircraft acoustic performances in real operation in airport under consideration - it is very important for airport capacity assessment from operational and environmental points of view.

Also an airport monitoring system can assist:

(i) in answering noise complaints about aircraft operations from the general public and their enquiries;

(ii) detecting unusual flight events (measurement and verification of noise levels by aircrafts, air companies);

(iii) educating pilots, airlines, airport proprietors, the public (detection of operations which have not complied with flight corridor requirements;

(iv) obtaining statistical data using an objective resources (aircraft types, operating times, usage of flight tracks and routes, of runways, complaints, etc.);

(v) applying research tools to assist the airport in performing certain tasks as required and mandated (planning of airspace usage around the airport, detection of operations which have not complied with flight corridor requirements, determination of the contribution of aircraft to overall noise exposure);

(vi) assessing compliance with mandatory noise levels, established by a governmental entity, etc (measurement and verification of noise levels and flight procedures by aircraft types, air companies, detection of occurrences of excessive noise levels from aircraft operations, etc ).

The benefits of operating a noise and flight path monitoring system are substantial. However, these benefits may not be fully realised and the operating agency's credibility may be reduced if insufficient resources are provided to oversee the system's operation and ensure its accuracy. Points to note include the following:

a) The noise and flight path monitoring system generates vast quantities of data, and a methodical process of summarizing and reporting the data is vital. This may take the form of standardized report formats, produced at pre-determined intervals.

b) It is essential to check the accuracy of the data carefully before it is issued publicly. This relates particularly to the noise data, where the system may be performing extensive mathematical calculations on data which has been gathered automatically from unattended instrumentation. With the logarithmic processing which is basic to sound level calculations, it does not require many incorrect inputs to severely distort a summarised average. 
c) It is essential to keep records of system outages, particularly in regard to flight track information, to avoid the circumstance where a complainant may be told there was no aircraft operation at the time and place corresponding to that complained about, when in fact there was an operation, but it was not recorded due to a system outage.

d) There is a need to run a preventative maintenance and calibration program, as described in the section on Noise Monitoring Terminals, and this will be an ongoing cost. If the system is used to detect violations of noise limits and/or of flight corridor boundaries, for the purpose of prosecution of offenders, then the records of maintenance and calibration data may become evidentiary material in legal proceedings.

e) The process of installation of a noise and flight path monitoring system may be seen as a service to the community in helping to deal with the adverse affects of aircraft operations. However, while the system will provide for a more informed discussion, it is not in itself a solution to those adverse affects.

\section{РЕФЕРАТ \\ Міхал Букала ${ }^{1}$, Олександр Запорожещь ${ }^{2}$, Володимир Ісаєнко ${ }^{3}$, Анджей Чила ${ }^{1}$ \\ ISVANTEKSpzo.o., mbukala@svantek.com.pl,andrzej.chyla@gmail.com, \\ ${ }^{2}$ Кафедра чисельних методів Жешувського політехнічного університету, zарогоz@prz.edu.pl, mdobrzanska@prz.edu.pl, \\ ${ }^{3}$ Наиіональний авіаційний університет, post@nau.edu.иа \\ МОНТТОРИНГ ШУМУ ДЛЯ ПОКРАЩЕННЯ ЕКСПЛУАТАЦЙНИХ ХАРАКТЕРИСТИК ПОВІТРЯНОГО СУДНА ПОБЛИЗУ АЕРОПОРТІВ}

Повітряні перевезення $\epsilon$ дуже вигідними для національної та міжнародної економіки, але вони створюють авіаційний шум - деякі види збитків, особливо для населення та екологічних систем в районі аеропорту. Рівень авіаційного шуму є предметом сертифікації літальних апаратів, виробництво та експлуатація літаків 3 невідповідним рівнем шуму $є$ незаконною. Постійний та/або тимчасовий шумовий моніторинг повинен проводитись, як правило, у місцевій громаді за умови, що шум повітряного судна перевищує "прийнятний" або законно допустимий рівень шуму, і в зв'язку з цим необхідно послатися на законодавчий контроль шумів повітряних суден. Кількість і місце розташування терміналів у системі моніторингу шумів $\epsilon$ важливими залежно від конкретної ролі, яку вони повинні відігравати в цій системі.

Ключові слова: авіаційний шум, шумовий моніторинг, термінали в системі моніторингу шуму.

$$
\begin{aligned}
& \text { PЕФЕРАТ } \\
& \text { Михал Букала', Александр Запорожеи }{ }^{2}, \text { Владимир Исаенко }{ }^{3} \text {, Анджей Чила }{ }^{1} \\
& { }^{I} \text { SVANTEK Spzo.o., mbukala@svantek.com.pl,andrzej.chyla@gmail.com, } \\
& { }^{2} \text { Кафедра численных методов Жешувского политехнического университета, zарогоz@prz.edu.pl, } \\
& \text { mdobrzanska@prz.edu.pl, } \\
& { }^{3} \text { Национальный авиационный университет, post@nau.edu.иа } \\
& \text { МОНИТОРИНГ ШУМА ДЛЯ УЛУЧШЕНИЯ ЭКСПЛУАТАЦИОННЫХ ХАРАКТЕРИСТИК } \\
& \text { ВОЗДУШНОГО СУДНА ВБЛИЗИ АЭРОПОРТОВ }
\end{aligned}
$$

Воздушные перевозки являются очень выгодными для национальной и международной экономики, но они создают авиационный шум - некоторые виды убытков, особенно для населения и экологических систем в районе аэропорта. Уровень авиационного шума является предметом сертификации летательных аппаратов, производство и эксплуатация самолетов с несоответствующим уровнем шума является незаконной. Постоянный и/или временный шумовой мониторинг должен проводиться, как правило, в местной общине при условии, что шум воздушного судна превышает "приемлемый" или законно допустимый уровень шума, и в связи с этим необходимо ссылаться на законодательный контроль шумов воздушных судов. Количество и местоположение терминалов в системе мониторинга шумов важны в зависимости от конкретной роли, которую они должны играть в этой системе.

Ключевые слова: авиационный шум, шумовой мониторинг, терминалы в системе мониторинга шума. 


\title{
ABSTRACT \\ Mikhal Bukala ${ }^{1}$, Oleksandr Zaporozhets ${ }^{2}$, Volodymyr Isaienko ${ }^{3}$, Andrzej Chyla ${ }^{1}$ \\ ${ }^{1}$ SVANTEK Spzo.o., mbukala@svantek.com.pl,andrzej.chyla@gmail.com, \\ ${ }^{2}$ Department of Quantitative Methods of Rzeszow University of Technology, zaporoz@prz.edu.pl, mdobrzanska@prz.edu.pl, \\ ${ }^{3}$ National Aviaiton University, post@nau.edu.ua \\ NOISE MONITORING FOR IMPROVEMENT OF OPERATIONAL PERFORMANCES \\ OF THE AIRCRAFT IN VICINITY OF AIRPORTS
}

Air transportation is very beneficial for national and international economy, but it produces an aircraft noise - some kinds of damages, particularly for population and environmental systems in airport vicinity. Aircraft noise levels are subject of aircraft certification, the aircraft with incorrect levels of noise are illegal to be produced and operated. Permanent or/and temporary noise monitoring to be undertaken usually in local community on assumption that aircraft noise will exceed what is considered 'acceptable' or legally permissible level of noise, and in this connection it is necessary to refer to the legislative control on aircraft noise. The number and location of the terminals in noise monitoring system is important depending upon the specific role they are to play inside this system.

Key words: aircraft noise, noise monitoring, terminals in noise monitoring system.

\section{REFERENCES}

1. Economic Benefits from Air Transport in Poland. Poland country report - Oxford: Oxford Economics, 2011. - 25 p. - (OX1 1HB).

2. Prawo ochrony środowiska. - Dz. U. z 2013 r. poz. 1232 oraz z 2014 r. poz. 40, 47.

3. ICAO Annex 16 to the Convention on International Civil Aviation, Vol. 1, Environmental Protection, Aircraft Noise. - ICAO, 2011. - 226 p.

4. Polish Aviation Law [Electronic reference]. - 2017. - Access mode:

http://prawo.sejm.gov.pl/isap.nsf/DocDetails.xsp?id=WDU20170000959.

5. Monitoring as an instrument for aircraft noise nuisance reduction [O. Zaporozhets, A. Jagniatinskis, B. Fiks, et al.]. // Proc. The $7^{\text {th }}$ World Congress "Aviation in the XXI-st Century", September 19-21. - Kyiv, 2016. P. 5.4.39-5.4.41.

6. On Board a Sustainable Future. ICAO Environmental Report [Electronic reference]: ICAO. - 2016.

- Access mode: https://www.icao.int/environmental-

protection/Documents/ICAO\%20Environmental\%20Report\%202016.pdf.

7. Zaporozhets $O$. AIRCRAFT NOISE: assessment, prediction and control. / O. Zaporozhets, V. Tokarev, K. Attenborough. - CRC Press Reference, March 31, 2017. - 420 p. (ISBN 9781138073029).

DOI: doi.org/10.18372/38225

UDC: 504.5-046.55:001.891.54:502.51(045)

\subsection{ESTIMATION OF RADIOCAPACITY AND RELIABILITY OF WATER ECOSYSTEMS}

\author{
Yuri Kutlakhmedov ${ }^{1,2}$, Iryna Matvieieva ${ }^{2}$, Andrian Iavniuk ${ }^{2}$, \\ Valentyna Groza ${ }^{2}$, Iryna Burlakova ${ }^{2}$
}

After the accident at the Chernobyl Nuclear Power Plant large territories of Belarus, Ukraine and Russia were polluted [1,2]. Almost all of the contaminated land lies on the water catchment area of the Dnipro, so as a result of the surface runoff, radionuclide falls in waters of the Dnipro reservoirs cascade.

For assessment of radioactive contamination the following main concepts have been used.

Reliability - the fundamental property of biological objects that determines their existence and effective functioning in a randomly varying environmental conditions and time. The measure of reliability - the probability of fail-save existence of the system, which can vary from 0 to 1 . 